\title{
Sosyal Bilgiler Dersinde Ara Disiplinlerden Yararlanılmasına İlişkin Öğretmen
}

\author{
Görüșleri*
}

Teachers' Views about Using Cross-Curricular Themes in the Social Studies Course

Tuba ÇENGELCİ KÖSE

Anadolu University, Turkey
tubacengelci@anadolu.edu.tr

\section{Ömür GÜRDOĞAN BAYIR}

Anadolu University, Turkey

ogurdogan@anadolu.edu.tr

\author{
Nur Leman BALBAĞ \\ Anadolu University, Turkey \\ nlgoz@anadolu.edu.tr
}

\begin{abstract}
$\ddot{O} z^{1}$
Yapılandırmacı öğrenme 1şığında hazırlanan Sosyal Bilgiler Öğretim Programında ara disiplin anlayışı bir yenilik olarak yer almıştır. Ara disiplinlerle ilişkilendirme öğrencilerin çok yönlü gelişmesine olanak tanımaktadır. Bu nedenle öğretmenlerin öğretme-öğrenme sürecinde ara disiplinlerle ilişkilendirmeye önem vermesi gerekmektedir. Bu bağlamda araştırmanın amacı ilkokul 4. sınıfı okutan öğretmenlerin Sosyal Bilgiler dersinde ara disiplinlerden yararlanılmasına ilişkin görüşlerini belirlemektir. Tarama ${ }^{2}$ modelinde desenlenen bu araştırma kapsamında 4. sınıfları okutan sınıf öğretmenlerinden araştırmacılar tarafından oluşturulan anket aracıllğıyla veri toplanmıştır. Araştırmada nicel verilerin analizinde yüzde, frekans ve ki kare kullanılırken, nitel verilerin analizinde betimsel analiz tekniği kullanılmıştır. Araştırma sonucunda sınıf öğretmenlerinin Sosyal Bilgiler dersinde ara disiplinlerden yararlanmayı önemsediği, ara disiplinlerden yararlanmanın öğrencilere çeşitli bilgi, beceri ve değerler kazandırdığını düşündükleri, öğretmenlere arasında işbirliğine gereksinim duydukları ancak zamanın az olması, materyal eksikliği, kaynak kişilere ulaşamama gibi sorunlar yaşadıkları ortaya çıkmışır. Öğretmenlerin bu konuda seminerlere ihtiyaç duyduğu ve programda buna ek bilgilendirmelerin yapılması gerektiğini belirttikleri görülmüştür. Araştırma sonunda elde edilen sonuçlar bağlamında öneriler getirilmiştir.
\end{abstract}

Anahtar sözcükler: Sosyal Bilgiler, ara disiplinler, ilkokul, sınıf öğretmeni

\footnotetext{
${ }^{1}$ Araştırma makalesi, ilk gönderim tarihi: 29.04.2016 Kabul tarihi: 04.08.2016

2 *Bu makale III. Uluslararası Sosyal Bilgiler Eğitimi Sempozyumu'nda sunulan bildirinin genişletilmiş biçimidir.
} 


\begin{abstract}
Cross-curricular theme approach is considered as a new approach in the Social Studies Education Program which was prepared in light of constructivist learning theory. Cross-curricular themes help multi-dimensional development of students. Therefore, teachers should integrate content of the course with cross-curricular themes in teaching-learning process. Due to the fact that the current study aims to determine primary school teachers' views about using cross-curricular themes in the 4th grade Social Studies course, the research is designed in the survey model. Data of the study were collected through questionnaire prepared by researchers from primary school teachers who were teaching at the 4th grade. Percentage, frequency, and chi-square were used to analyze quantitative data of the study. In addition to this descriptive analysis was conducted to analyze qualitative data. Findings of the research revealed that teachers pay attention to using cross-curricular themes in the Social Studies course. They think that cross-curricular themes help students gain various information, skills, and values. They need to cooperate with colleagues about cross-curricular themes. However, they have problems about timing, absence of materials, and resource people. It is seen that teachers need seminars about this issue and they need extra-information about cross-curricular themes in the education program. Suggestions were put forth in light of results of the study.
\end{abstract}

Key words: Social studies, cross-curricular themes, primary school, primary school teacher

\title{
Giriş
}

Toplumların gereksinim duyduğu nitelikli bireyler yetiştirilmesi öğretim programlarında belirlenen bilgi, beceri ve değerlerle sağlanmaktadır. Bu bağlamda programların gerek bilimsel gerek teknolojik gerekse toplumsal gelişmeler 1şı̆̆ında düzenlenmesi önemlidir. Böylece gelişmeleri takip eden bireyler yetiştirilerek onların topluma uyumu kolaylaşmaktadır. Türkiye'de bilim ve teknolojide meydana gelen gelişmeler, nitelikli insan gücüne duyulan gereksinim ve eğitim bilimleri alanındaki gelişmeler doğrultusunda eğitim programları gözden geçirilmiş ve Milli Eğitim Bakanlığı (MEB) tarafından 2005-2006 öğretim yılından itibaren de ülke çapında yaygınlaştırılmıştır. Bu programlar zorunlu eğitimin 12 yıla çıkarılmasıyla birlikte güncellenmiştir. Yapılan değişikliklerle birlikte uygulamaya konulan programlardan biri de Sosyal Bilgiler Öğretim Programıdır. 
Yapılandırmacı öğrenme yaklaşımı 1şı̆̆ında hazırlanan Sosyal Bilgiler Öğretim Programında daha önceki programlarda yer almayan "ara disiplin" anlayışı görülmektedir. Programda ara disiplinler derslerle yaşam arasında bağlantı kuran alanlar biçiminde tanımlanmaktadır. Sosyal Bilgiler Programında afetten korunma ve güvenli yaşam, kariyer bilinci geliştirme, girişimcilik, spor kültürü ve olimpik eğitim, insan hakları ve vatandaşlık, özel eğitim, rehberlik ve psikolojik danışma ve sağlık kültürü ara disiplinleri yer almaktadır (MEB, 2004). Sosyal Bilgiler Öğretim Programında öğretmenin ünitede hangi kazanımı işlerken hangi ara disiplin ile ilişkilendirmesi gerektiği açıklamalar bölümünde verilen semboller yolu ile anlaşılmaktadır. Açıklamalarda yer alan “实"sembolü, verilmiş olan ara disiplin ile kazanımın ilişkilendirilmesi gerektiğini göstermektedir. Ayrıca hangi ara disiplin kazanımının hangi konudaki kazanım ile ilişkilendirilmesi gerektiği programda "Sosyal Bilgiler Dersi Öğretim Programı Kazanımları ile Eşleşen Ara Disiplin Kazanımları Tablosu”nda verilmiştir. Öğretmenlerden bu tablodan hareketle ilişkilendirmeleri yapmaları beklenmektedir.

Öğretmenlerin derslerde belirlenen bu farklı alanlarla ilişkilendirme yapmaları öğrencilerin farklı konularda da bilgi, beceri ve değerler edinmelerini sağlayacaktır.

Öğrencilerin temel yaşam becerilerini kazanma ve kişisel niteliklerini artırma bağlamında öğretim programlarında öngörülen ara disiplinler, ana derslerin yanında derslerde işlenen temalarla ders dışı konuları kapsamaktadır (Eraslan, 2011: 86). Başka bir deyişle, ara disiplinler ana disiplinlerle açık ve kapsayıcı biçimde örtüşen ve öğretim programlarında program hazırlama sürecinde göz önünde bulundurulan diğer disiplinlerdir (ERG, 2005: 17). Bu bağlamda, ara disiplin yaklaşımı programda tek başına bir ders olarak yer almayan ve diğer derslerin içerisinde bulunarak öğrencilerin çok yönlü düşünmesini sağlayan bir yaklaşımdır (Kansızoğlu, 2014: 77). Ara disiplinin, eğitim etkinliklerine yol gösteren çekirdek içerik olma ve herhangi bir ders ile sınırlandırılmama özellikleri bulunmaktadır. Ara disiplinler yeni dersler üretmek yerine üretilen içeriklerin programa yerleştirilmesini sağlamaktadır (Yus, 1998'den 
akt: Naval, Printe ve Iriarte, 2003: 4). Özetle ara disiplinler sosyal öneme sahip eğitsel konular ve değerler üzerindeki güncel açıklamalardır. Ayrıca ara disiplinler yaşamda karşılaşılabilecek tüm olaylarla ilgilidir (Finnish National Board of Education, 2003: 26).

Ara disiplinler okul ve okul dişında geliştirilen, ilkokuldan ortaöğretime kadar devam eden süreci kapsayan alanlardır (MELS, 2008a: 33). Aslında ara disiplinlerin öğrencilerin dünyayı anlamlandırmaları ve yaşam becerileri kazanmaları için bütünleştirici bir etkisi vardır. Çünkü programların amaçlarına ulaşmasında öğrenciler yaşantı zenginliğine gereksinim duymaktadırlar (Seçkin, 2010). Ara disiplinleri kullanmanın amaçları şöyle ifade edilebilir (DENI, 2008'den akt: Gözütok ve Alkın Şahin, 2014: 297, Finnish National Board of Education, 2003: 27; CCPE, 2008; ERES, 2010; Vogt, 1997):

- Çalışma ortamlarını ve çağdaş olguları gözlemleme ve analiz edebilme,

- Gelecek için gerekli düşünceleri açıklama,

- Geleceğe bakış açısına göre kendi yaşam biçimini değerlendirme,

- İstediği gelecek için seçimler yapma,

- Kendilerine ve başkalarına saygı duyma,

- Fiziksel, psikolojik ve sosyal yeteneklerini geliştirme,

- Kendilerini ve başkalarını her yönüyle anlama,

- İşbirliği, sorumluluk ve dayanışmayı artırma,

- Değer, tutum ve davranış kazanımını sağlama,

- Toplumsal yaşama uyum sağlama,

- Öğrendiklerini uygulama şansı bulma.

Çocukların kişisel, sosyal ve entelektüel anlamda bütünüyle gelişimini sağlayan eğitim içeriği olarak ele alınan ara disiplinler okulların öğrencilere var olan dersler kapsamında kazandırılan bilgi ve becerilerden daha fazlasını kazandırmaya, öğrencilerin sosyal, bilişsel, duygusal ve psikomotor gelişimlerini doğrudan etkileyen çeşitli konuları öğrenmesine yardımcı olmaktadır 
(British Columbia Ministry of Education, 2013). Bu nedenle, öğrencilerin çok yönlü gelişmesini sağlamak için ara disiplinlerin öğretimi üzerinde durulmalıdır.

Ara disiplinlerin planlanması, uygulanması ve değerlendirilmesi bütün öğretmenlerin ve okul personelinin ortak sorumluluğudur (MELS, 2008b'den akt: Gözütok ve Alkın, 2008). Öğretmenler, öğrencilerin ara disiplin kazanımlarına ulaşmalarında ve ara disiplinlerin planlanması ve uygulanmasında öncelikli bir role sahiptirler (MELS, 2008b'den akt: Taş, 2010: 14). Ara disiplinlerin öğretmenler tarafından etkili bir biçimde uygulanması öğretmenlere öğretmen eğitimi programlarında, hizmet içi eğitim programlarında, öğretim programlarında ve ders kitaplarında ara disiplin yaklaşımının amacına, işlevine, felsefesine ve uygulamasına ilişkin gerekli açıklamanın, bilgilendirmenin, yönlendirmenin yapılmasına ayrıca öğretmenlerin ara disiplin yaklaşımına ilişkin farkındalıklarının bilimsel araştırmalarla değerlendirilip, değerlendirme sonuçlarının program geliştirme çalışmalarına yansıtılmasına bağlıdır (Gözütok ve Alkın, 2008). Bu nedenle, ara disiplinlerin öğretmenler tarafından nasıl işe koşulduğunu ortaya koyan çalışmaların yapılmasına gereksinim duyulmuştur.

Ara disiplinlerin Sosyal Bilgiler dersinde uygulanması konusunda alanyazında çok fazla çalışma olmadığı görülmektedir. Ara disiplinlerle ilgili yapılan çalışmaların Sosyal Bilgiler programında ara disiplinlerle ilişkilendirmenin ortaya konulması (Kaymakçı, 2012), Sosyal Bilgiler dersindeki ara disiplinlerin sınıf içi uygulamalarına ilişkin öğretmen görüşlerinin alınması (Ermiş, 2008), ilköğretim 4. ve 5. sınıf Sosyal Bilgiler dersi programında yer alan ara disiplinlerin kazanımlarla uyumu ve ara disiplinlerden yararlanma konusuna ilişkin öğretmen görüşlerinin belirlenmesi (Çakırlar, 2011), ara disiplin alanı olarak insan hakları ve vatandaşlık eğitimi ile ilgili ilköğretim öğretmenlerinin yeterlik algıları (Ülger ve Yel, 2013) ile insan hakları ve vatandaşlık eğitimi ara disiplin uygulamasının Sosyal Bilgiler öğretmenlerinin görüşleri bağlamında değerlendirilmesi (Ülger, 2013) biçiminde gerçekleştirildiği söylenebilir. Sosyal Bilgiler dersinde ara disiplinlerden etkili biçimde yararlanılması öğretmenlerin ara 
Anadolu Journal of Educational Sciences International, July 2016, 6(2)

disiplinler konusunda bilgi sahibi olması ve ara disiplin etkinliklerini öğretme-öğrenme sürecinde uygulaması ile doğrudan ilişkilidir. Sosyal Bilgiler öğretiminin ayrı bir ders olarak programda yer aldığı 4. sınıf düzeyinden başlanarak ara disiplinlerden yararlanılması Sosyal Bilgiler öğretimine zenginlik katacaktır. Bu nedenle 4. sınıfta Sosyal Bilgiler dersini yürüten sınıf öğretmenlerinin Sosyal Bilgiler dersinde ara disiplinlere ilişkin görüşlerinin belirlenmesi, ara disiplin anlayışıyla ilgili uygulamaların ve yaşanan sorunların belirlenmesi bakımından önem taşımaktadır.

Bu araştırmada ilkokul 4. sınıfı okutan öğretmenlerin Sosyal Bilgiler dersinde ara disiplinlerden yararlanılmasına ilişkin görüşlerini belirlemek amaçlanmıştır. Bu kapsamda şu sorulara yanıt aranmıştır:

- 4. sınıf öğretmenlerinin Sosyal Bilgiler dersi programında ara disiplinlerle ilişkilendirmeye ilişkin görüşlerinin dağılımı nedir?

- 4. sınıf öğretmenlerinin Sosyal Bilgiler dersi programında ara disiplinlerle ilişkilendirmeye ilişkin görüşleri kişisel özelliklerine göre (cinsiyet, mesleki deneyim ve mezun olunan program) değişmekte midir?

- 4.sınıf öğretmenlerinin Sosyal Bilgiler dersinde ara disiplinlerden daha etkili yararlanılmasına ilişkin önerileri nelerdir?

\section{Yöntem}

$\mathrm{Bu}$ araştırma tarama modelinde desenlenmiştir. Tarama modelleri, geçmişte ya da varolan durumu yansıtan, betimsel araştırma yaklaşımlarıdır (Karasar, 2007). Bu kapsamda, araştırmada sınıf öğretmenlerinin Sosyal Bilgiler dersinde ara disiplinlerden yararlanmasına ilişkin görüşleri ayrıntılı olarak açıklanmaya çalışılmıştır. 


\section{Evren ve Örneklem}

Araştırmanın çalışma evrenini 2013-2014 öğretim y1lında Eskişehir'in Tepebaşı İlçesi’nde görev yapan 4. sınıf öğretmenleri oluşturmuştur. Araştırmada basit seçkisiz örnekleme yöntemi kullanılmıştır. Bu örnekleme yönteminde evren listesinden örneklem için istenilen sayıda kişinin rastgele seçilmesi önemlidir. Bu örneklem türünde her bir kişinin örnekleme dahil olmada şansı eşittir (Çınkır ve Demirkasımoğlu, 2015: 335; Ekiz, 2013: 104). Bu kapsamda araştırmaya 101 ilkokul 4. sınıf öğretmeni katılmıştır. Araştırmaya katılan öğretmenlerin özellikleri Tablo 1'de gösterilmiştir:

Tablo 1

Katılımcı özellikleri

\begin{tabular}{llll}
\hline & & f & $\%$ \\
\hline \multirow{3}{*}{ Cinsiyet } & Kadın & 56 & 55,4 \\
\cline { 2 - 4 } & Erkek & 45 & 44,6 \\
\hline \multirow{3}{*}{ Mesleki deneyim } & $1-10$ y1l & 30 & 29,7 \\
\cline { 2 - 4 } & $11-20$ yıl & 50 & 49,5 \\
\cline { 2 - 4 } Mezun olunan okul & 21 ve üstü & 21 & 20,8 \\
\hline & Eğitim Fakültesi & 86 & 85,1 \\
\cline { 2 - 4 } & Diğer & 15 & 14,9 \\
\hline & Toplam & 101 & 100 \\
\hline
\end{tabular}

Tablo 1'de görüldüğü gibi, araştırmaya 56 kadın, 45 erkek olmak üzere toplam 101 sınıf öğretmeni katılmıştır. Araştırmaya katılan öğretmenlerin çoğunluğu 11-20 yıl arasında mesleki deneyime sahiptir. Ayrıca öğretmenlerin yine çoğunluğu eğitim fakültesi mezunudur.

\section{Verilerin Toplanması ve Analizi}

Araştırmada verilerin toplanmasında araştırmacılar tarafından geliştirilen anket kullanılmıştır. Anket, bireyin özelliklerine ilişkin çeşitli madde türleriyle ilgili bilgi toplamak amaciyla oluşturulmuş yapılandırılmış yazılı görüşme tekniğidir (Erkuş, 2005). Anketin taslak biçimi oluşturulduktan sonra uzmanların ve öğretmenlerin görüşlerine sunulmuşstur. Ankete toplam altı alan uzmanından gelen görüşler doğrultusunda son biçimi verilmiştir. Anket üç bölümden 
oluşmaktadır. Birinci bölümde öğretmenlerin kişisel bilgilerini belirlemeye yönelik sorular yer almıştır. İkinci bölümde öğretmenlerin Sosyal Bilgiler dersinde ara disiplinlerden yararlanılmasına ilişkin görüşlerini belirlemek amacıyla 32 maddeye yer verilmiştir. $\mathrm{Bu}$ maddeler öğrenci, program ve öğretmen boyutları altında toplanmıştır. Anketin üçüncü bölümünü Sosyal Bilgiler dersinde ara disiplinlerin sınıf içinde kullanılmasına ilişkin görüşlerini belirlemeye yönelik açık uçlu sorulara yer verilmiştir. Bu bölümde 3 tane açık uçlu soru yer almaktadir.

Araştırmada verilerin çözümlenmesinde, araştırmanın amaçları doğrultusunda betimsel istatistik (frekans) ve ki-kare tekniklerinden yararlanılmıştır. Ki-kare testi değişkenlere ilişkin gözlenen frekanslarla beklenen frekanslar arasındaki dağılımın istatistiksel bakımdan anlamlılığını test etmek amacıyla yapılmaktadır (Ural ve Kılıç, 2005). Yapılan ki kare analizlerinde anket maddeleriyle cinsiyet, mesleki deneyim ve eğitim durumu değişkenleri arasında ilişki durumuna bakılmıştır. Bu analiz sonucunda gözeneklerde 5 'in altında verilerin bulunması nedeniyle ilgili satır ve sütunlarda birleştirme (Özdamar, 1999; Öztürk, 2008; Ural ve K1lıç, 2005) yapılmıştır. Mesleki deneyim 1 yıl ve altı, 1-5 yıl, 6-10 yı1, 11-15 yıl, 16-20 yıl ve 21 yıl ve üstünde olarak belirlenmiş ancak birleştirme sonucunda 1-10 y1l, 11-20 yıl ve 21 y1l ve üstünde olarak analiz yapılmıştır. Bu işlemden sonra aralarında ilişki bulunan maddeler belirtilmiş ve maddelere ilişkin katılım oranlarının yüzdeleri verilmiştir. Araştırmada anlamlılık düzeyi .05 olarak alınmıştır. Araştırmada açık uçlu soruların analizinde betimsel analiz tekniği kullanılmıştır. Betimsel analiz elde edilen bulguların düzenlenmiş ve yorumlanmış biçimiyle okuyucuya sunulmasını amaçlamaktadır. Bu amaçla elde edilen veriler, öncelikle mantıklı ve anlaşılır biçimde betimlenmektedir. Daha sonra yapılan bu betimlemeler yorumlanmakta, neden-sonuç ilişkileri irdelenmektedir (Yıldırım ve Şimşek, 2006). Bu kapsamda veriler ankette yer alan açık uçlu soruların kapsamında kodlanmıştır. Daha sonra elde edilen bulgular şekille sunulmuş ve doğrudan alıntılara yer verilmiştir. 


\section{Bulgular ve Yorumlar}

$\mathrm{Bu}$ bölümde araştırmanın bulguları, araştırmanın amaçları doğrultusunda verilmiştir. $\mathrm{Bu}$ kapsamda öncelikle sınıf öğretmenlerinin ankete verdiği yanıtlar ankette oluşturulan boyutlar bağlamında frekanslarla sunulmuş, daha sonra ki kare sonucu verilmiş ve son olarak da açık uçlu sorulara verilen yanıtlar şekillerle gösterilmiştir. Sınıf öğretmenlerinin Sosyal Bilgiler dersinde ara disiplinlerden yararlanılmasına ilişkin ankette yer alan öğrenci boyutuna verdikleri yanıtlar Tablo 2'de gösterilmiştir.

Tablo 2

Sosyal Bilgiler dersinde ara disiplinlerden yararlanma konusunda öğrenci boyutuna ilişkin verilen yanıtların frekansları

\begin{tabular}{|c|c|c|c|}
\hline \multicolumn{4}{|l|}{ Sosyal Bilgiler Dersinde Ara Disiplinlerden Yararlanma } \\
\hline Öğrenci Boyutu & EVET & KISMEN & HAYIR \\
\hline $\begin{array}{l}\text { Sosyal Bilgiler dersinde ara disiplinlere yer verilmesi } \\
\text { öğrencilerin, }\end{array}$ & $\mathrm{f}$ & f & $\mathrm{f}$ \\
\hline $\begin{array}{l}\text { afetten korunma ve güvenli yaşam konusunda temel bilgi ve } \\
\text { becerileri kazanmasını sağlar. }\end{array}$ & 86 & 14 & 1 \\
\hline girişimcilikle ilgili temel kavramları öğrenmesini sağlar. & 58 & 39 & 4 \\
\hline $\begin{array}{l}\text { haklarını nasıl koruyabileceği konusunda bilgi edinmesini } \\
\text { sağlar. }\end{array}$ & 74 & 26 & 1 \\
\hline $\begin{array}{l}\text { etkili vatandaşlık bilgi, beceri ve değerlerini kazanmasını } \\
\text { sağlar. }\end{array}$ & 71 & 29 & 1 \\
\hline liderlik becerilerinin farkına varmasını sağlar. & 60 & 37 & 4 \\
\hline dikkatinin dağılmasına neden olur. & 11 & 26 & 64 \\
\hline $\begin{array}{l}\text { toplumdaki işbölümü ve kariyer alanlarına örnek vermesini } \\
\text { sağlar. }\end{array}$ & 73 & 27 & 1 \\
\hline farklılıklara karşı anlayış ve saygı göstermesini sağlar. & 74 & 26 & 1 \\
\hline araştırma becerilerini geliştirir. & 69 & 31 & 1 \\
\hline düşünme becerilerini geliştirir. & 64 & 36 & 1 \\
\hline konulara çok yönlü bakmasını sağlar. & 66 & 34 & 1 \\
\hline sosyal problemlere duyarlı olmasını sağlar. & 70 & 28 & 3 \\
\hline problem çözme becerilerinin gelişimine katk1 sağlar. & 64 & 35 & 2 \\
\hline derse olan motivasyonunu artırır. & 56 & 44 & 1 \\
\hline
\end{tabular}


Tabloda görüldüğü gibi, 4. sınıfları okutan sınıf öğretmenlerinin büyük çoğunluğu (86) Sosyal Bilgiler dersinde ara disiplinlerden yararlanmanın öğrencilere afetten korunma ve güvenli yaşam konusunda temel bilgi ve beceriler kazandırdığını düşünmektedir. Ayrıca öğretmenlerin çoğunluğunun Sosyal Bilgiler dersinde ara disiplinlerden yararlanmanın öğrencilere haklarını nasıl koruyacağı konusunda bilgi verdiği (74) ve öğrencilerin farklılıklara karşı anlayış ve saygı göstermesini sağladığı (74) görüşlerine katıldığı görülmüştür. Sınıf öğretmenleri Sosyal Bilgilerde ara disiplinlerin öğrencilere etkili vatandaşlık konusunda bilgi, beceri ve değer kazandırdığını (71) ve sosyal problemlere duyarlı olmalarını sağladığını (70) düşündükleri ortaya çıkmıştır. Aynı zamanda sınıf öğretmenleri Sosyal Bilgiler dersine ara disiplinlerin dikkat dağınıklığına neden olmadığı (64) görüşüne sahiptir. Sınıf öğretmenlerinin bir kısmı (56) Sosyal Bilgiler dersinde ara disiplinlerin derse olan motivasyonu artırdığını düşünürken, bir kısmı ise (44) kısmen artırdığını düşünmektedir. Buna göre 4. sınıf öğretmenlerinin Sosyal Bilgiler dersinde ara disiplinlerden yararlanmanın öğrencileri olumlu yönde etkileyeceğini düşündükleri söylenebilir. Sınıf öğretmenlerinin Sosyal Bilgiler dersinde ara disiplinlerden yararlanılmasına ilişkin ankette yer alan öğretmen boyutuna verdikleri yanıtlar Tablo 3'de gösterilmiştir. 
Anadolu Journal of Educational Sciences International, July 2016, 6(2)

Tablo 3

Sosyal Bilgiler dersinde ara disiplinlerden yararlanma konusunda öğretmen boyutuna ilişkin verilen yanttarın frekanslart

\begin{tabular}{|c|c|c|c|}
\hline \multicolumn{4}{|l|}{ Sosyal Bilgiler Dersinde Ara Disiplinlerden Yararlanma } \\
\hline Öğretmen Boyutu & EVET & KISMEN & HAYIR \\
\hline Sosyal Bilgiler dersinde, & f & f & $\mathrm{f}$ \\
\hline ara disiplinlerle ilişkilendirme zaman kaybına neden olur. & 21 & 29 & 51 \\
\hline $\begin{array}{llcc}\text { ara disiplinlerin yer alması farklı branşlardaki } \\
\text { öğretmenlerin işbirliği yapmasını sağlar. }\end{array}$ & 48 & 48 & 5 \\
\hline $\begin{array}{l}\text { ara disiplinlere yer verilmesi ek ders planları yapmayı } \\
\text { gerektirir. }\end{array}$ & 25 & 32 & 44 \\
\hline $\begin{array}{l}\text { ara disiplinlere yer verilmesi problemlerin yaşanmasına yol } \\
\text { açar. }\end{array}$ & 12 & 34 & 55 \\
\hline $\begin{array}{l}\text { ara disiplinlerin uygulanması öğretmenlerin ve okul } \\
\text { personelinin işbirliğini gerektirir. }\end{array}$ & 60 & 40 & 1 \\
\hline $\begin{array}{l}\text { ara disiplinlerin kullanımına yönelik öğretmenlere } \\
\text { bilgilendirme yapılmasına gerek yoktur. }\end{array}$ & 19 & 28 & 54 \\
\hline
\end{tabular}

Tabloda görüldüğü gibi, 4. sınıfı okutan sınıf öğretmenlerinin çoğunluğunun (60) Sosyal Bilgiler dersinde ara disiplinlerden yararlanmanın öğretmen ile okul personeli arasında işbirliği gerektirdiğini düşünmektedirler. Sınıf öğretmenleri Sosyal Bilgiler dersinde ara disiplinlerin yer almasının farklı branşlardaki öğretmenlerin işbirliği yapmasını sağladığı ifadesine eşit biçimde (48) evet ve kısmen seçeneklerini işaretleyerek katılmışlardır. Sınıf öğretmenlerinin çoğunluğu Sosyal Bilgiler dersinde ara disiplinlere yer verilmesinin problemlerin yaşanmasına yol açmayacağını (55), ara disiplinlerden yararlanma konusunda bilgilendirme yapılması gerektiğini (54) ve ara disiplinlerle ilişkilendirmenin zaman kaybına neden olmayacağını (51) düşündükleri görülmüştür. Bu bağlamda, sınıf öğretmenlerinin Sosyal Bilgiler dersinde ara disiplinlerden yararlanmanın öğretmenleri olumsuz etkilemeyeceğini ve bu durumun işbirliği gerektirdiğini düşündükleri söylenebilir. Sınıf öğretmenlerinin Sosyal Bilgiler dersinde ara disiplinlerden yararlanılmasına ilişkin ankette yer alan program boyutuna verdikleri yanıtlar Tablo 4'de gösterilmiştir. 
Anadolu Journal of Educational Sciences International, July 2016, 6(2)

Tablo 4

Sosyal Bilgiler dersinde ara disiplinlerden yararlanma konusunda program boyutuna ilişkin verilen yanitlarin frekanslart

\begin{tabular}{|c|c|c|c|}
\hline \multicolumn{4}{|l|}{ Sosyal Bilgiler Dersinde Ara Disiplinlerden Yararlanma } \\
\hline Program Boyutu & EVET & KISMEN & HAYIR \\
\hline Sosyal Bilgiler dersinde, & $\mathrm{f}$ & f & $\mathrm{f}$ \\
\hline ara disiplinlere yer verilmesi dersin yapısına uygundur. & 79 & 21 & 1 \\
\hline $\begin{array}{l}\text { ara disiplinlere yer verilmesi günlük yaşamla ilişkilendirme } \\
\text { yapmayı kolaylaştırır. }\end{array}$ & 74 & 26 & 1 \\
\hline $\begin{array}{l}\text { ara disiplinlere yer verilmesi konuların pekiştirilmesini } \\
\text { sağlar. }\end{array}$ & 75 & 25 & 1 \\
\hline $\begin{array}{l}\text { ara disiplinlere yer verilmesi programın eksik kalan } \\
\text { yönlerini tamamlar. }\end{array}$ & 66 & 32 & 3 \\
\hline $\begin{array}{l}\text { ara disiplinlerle ilişkilendirmenin nasıl yapılacağına ilişkin } \\
\text { açıklamalar yetersizdir. }\end{array}$ & 28 & 47 & 26 \\
\hline $\begin{array}{l}\text { ara disiplinlere yer verilmesi programa zenginlik } \\
\text { katmaktadır. }\end{array}$ & 70 & 29 & 2 \\
\hline $\begin{array}{l}\text { ara disiplinlerle ilişkilendirme yapılması karmaşıklığa } \\
\text { neden olur. }\end{array}$ & 21 & 36 & 44 \\
\hline $\begin{array}{l}\text { ara disiplinlere yer verilmesi öğrenme alanları arasında } \\
\text { bütünlük oluşturmaktadır. }\end{array}$ & 70 & 28 & 3 \\
\hline $\begin{array}{l}\text { ara disiplinler, öğrencilerin yaşam boyunca karşılaşacakları } \\
\text { farklı disiplinlerden meydana gelir. }\end{array}$ & 66 & 34 & 1 \\
\hline $\begin{array}{l}\text { ara disiplinlere yer verilmesi dersin kazanımlarının davranış } \\
\text { haline dönüşmesine katkıda bulunur. }\end{array}$ & 74 & 26 & 1 \\
\hline ara disiplinlere daha çok yer verilmelidir. & 53 & 43 & 5 \\
\hline $\begin{array}{l}\text { ara disiplinlere yer verilmesi ders ile güncel olaylar arasında } \\
\text { bağlantı kurulmasına yardımcı olur. }\end{array}$ & 81 & 19 & 1 \\
\hline
\end{tabular}

Tabloda görüldüğü gibi, sınıf öğretmenlerinin çoğunluğunun (81) Sosyal Bilgiler dersinde ara disiplinlerden yararlanılmasının derste güncel olaylarla bağlantı kurulmasına olanak sağladığını belirtmişstir. Ayrıca Sosyal Bilgiler dersinde ara disiplinlerden yararlanmaya ilişkin dersin ara disiplinlere uygun olduğunu (79), ara disiplinlere yer vermenin konuları pekiştirdiğini (75), ara disiplinlerin günlük yaşamla ilişkilendirmeyi kolaylaştırdığını (74) ve ara disiplinlerden yararlanmanın kazanımların davranışa dönüşmesine katkıda bulunduğunu düşünmektedir. Sınıf öğretmenleri Sosyal Bilgiler Öğretim Programında ara disiplinlere ilişkin açıklamaları kısmen yetersiz (47) bulmuşlardır. Sınıf öğretmenlerin bir kısmı Sosyal Bilgiler dersinde ara disiplinlerin karmaşıklığa neden olmadığını (44) düşünürken, yine bir kısmı kısmen karmaşıklığa neden olduğunu (36) düşünmektedir. 
İlkokul 4. sınıfı okutan sınıf öğretmenlerinin Sosyal Bilgiler dersinde ara disiplinlerden yararlanmaya ilişkin görüşleri ile cinsiyet, mesleki deneyim ve eğitim durumu arasında ilişki olup olmadığı ki kare analizi ile ortaya konmuştur. Buna göre mesleki deneyim ile arasında ilişki bulunan madde Tablo 5'te gösterilmiştir.

Tablo 5

Mesleki deneyim ile "ara disiplinlerle ilişkilendirme zaman kaybına neden olur” maddesi arasındaki ilişki

\begin{tabular}{|c|c|c|c|c|}
\hline $\begin{array}{l}\text { Ara disiplinlerle ilişkilendirme } \\
\text { zaman kaybına neden olur. }\end{array}$ & & EVET & KISMEN & HAYIR \\
\hline \multirow[t]{2}{*}{$1-10$ yıl } & $\mathbf{N}$ & 11 & 6 & 13 \\
\hline & $\%$ & 36,7 & 20 & 43,3 \\
\hline \multirow[t]{2}{*}{ 11-20 yll } & $\mathbf{N}$ & 8 & 11 & 31 \\
\hline & $\%$ & 16,0 & 22,0 & 62,0 \\
\hline \multirow[t]{2}{*}{21 yıl ve üstü } & $\mathbf{N}$ & 2 & 12 & 7 \\
\hline & $\%$ & 9,5 & 57,1 & 33,3 \\
\hline \multirow[t]{2}{*}{ Toplam } & $\mathbf{N}$ & 21 & 29 & 51 \\
\hline & $\%$ & 20,8 & 28,7 & 50,5 \\
\hline$\chi^{2}=11,1 \mathrm{sd}=4$ & & & & \\
\hline
\end{tabular}

Tablo incelendiğinde, sınıf öğretmenlerinin Sosyal bilgiler dersinde ara disiplinlerle ilişkilendirmenin zaman kaybına neden olup olmadığına yönelik verdikleri yanıtlarda, 1-10 yıl mesleki deneyime sahip öğretmenlerin $(\% 43,3)$ ve 11-20 y1l mesleki deneyime sahip öğretmenlerin (\%62) zaman kaybına neden olmadığını belirttikleri, 21 yıl ve üstü deneyime sahip olan öğretmenlerin $(\% 57)$ ise kısmen zaman kaybına neden olduğunu belirttikleri görülmüştür. Buna göre sınıf öğretmenlerinin çoğunluğu $(\% 50,5)$ ara disiplinlerle ilişkilendirmenin zaman kaybına neden olmadığını düşündükleri söylenebilir. Ancak 1-10 yıl mesleki deneyime sahip öğretmenlerin $(\% 36,7)$ ara disiplinlerden yararlanmanın zaman kaybına neden olduğunu düşündükleri görülmüştür. Yine tabloda görüldüğü gibi, ara disiplinlerden yararlanmanın zaman kaybına neden olmadığını düşünen öğretmenler arasında mesleki deneyime göre farklılıklar olduğu ifade edilebilir. Yapılan ki kare testi sonuçlarına göre sınıf öğretmenlerinin 'sosyal bilgiler dersinde ara disiplinlerle ilişkilendirmede zaman kaybına 
yönelik’ verdikleri yanıtlar ile mesleki deneyim arasında anlamlı bir ilişki bulunmuştur $\left(\chi^{2}=\right.$ $11,1 ; \mathrm{p}<.05)$. Ankette yer alan diğer maddeler ve değişkenler arasında ise bir ilişki olmadığ ortaya çıkmıştır.

İlkokul 4. sınıfı okutan sınıf öğretmenlerinin Sosyal Bilgiler dersinde ara disiplinlerden yararlanılmasına ilişkin görüşleri şekillerle ortaya konmuştur. Buna göre oluşan temalar Şekil 1 'de sunulmuştur.

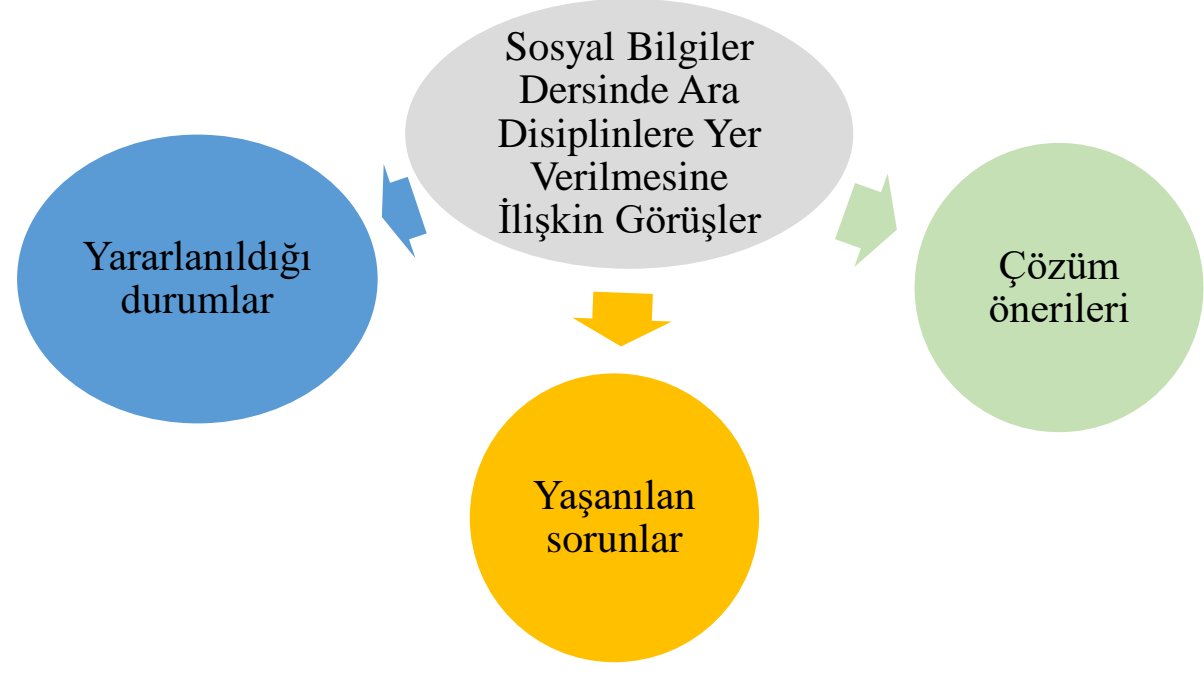

Şekil 1. Sosyal Bilgiler dersinde ara disiplinlerden yararlanmaya ilişkin oluşturulan temalar

Şekilde görüldüğü gibi, 4. sınıfları okutan öğretmenlerin Sosyal Bilgiler dersinde ara disiplinlerden yararlanılmasına ilişkin görüşleri yararlanıldığg durumlar, yaşanılan sorunlar ve çözüm önerileri temaları altında toplanmıştır. Buna ilişkin olarak öğretmenlerin Sosyal Bilgilerden dersinde ara disiplinlerden yararlandığı durumlar Şekil 2’de gösterilmiştir. 


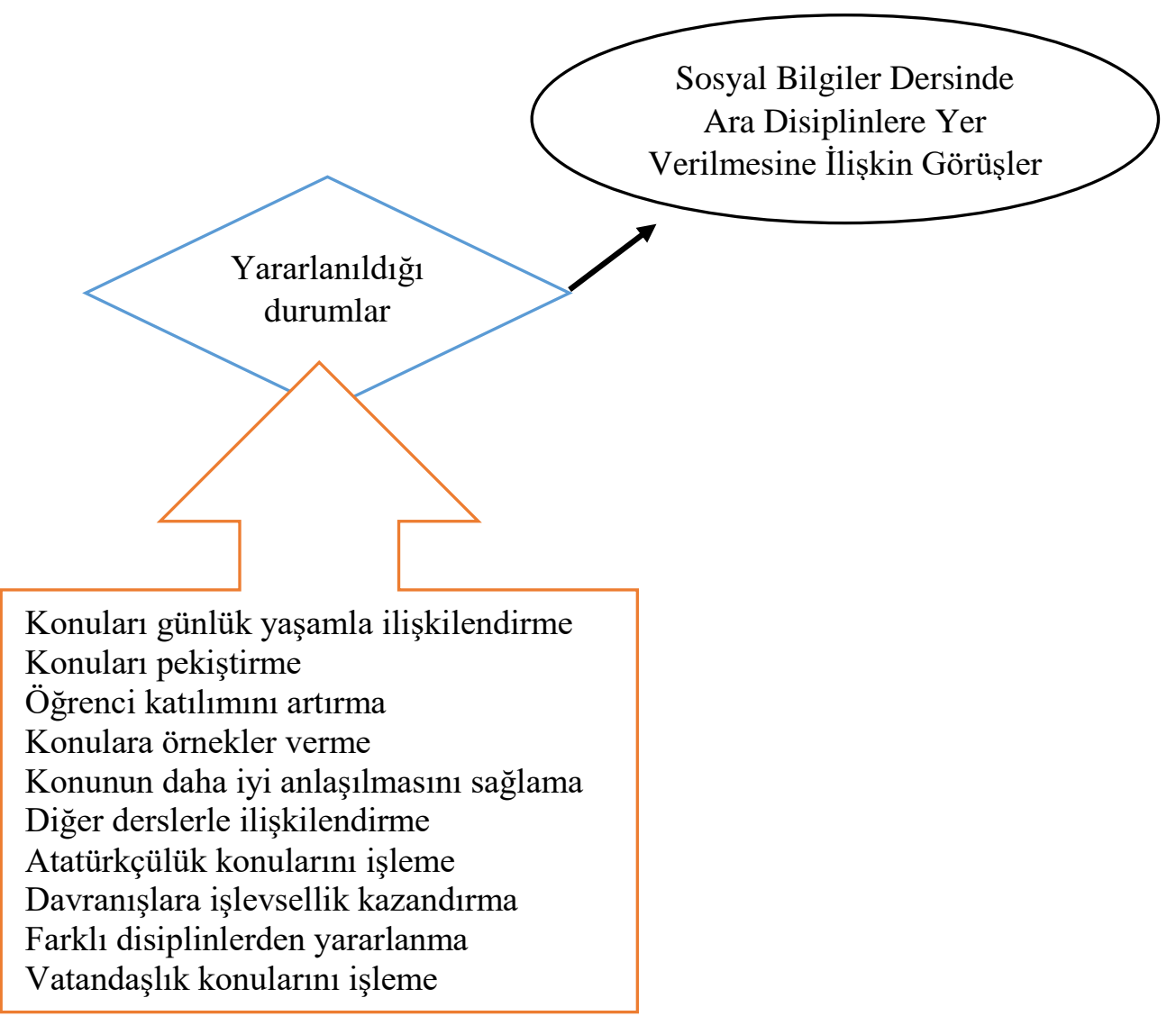

Şekil 2. Sosyal Bilgiler dersinde ara disiplinlerden yararlanılan durumlar

Şekilde görüldüğü gibi sınıf öğretmenleri Sosyal Bilgiler dersinde ara disiplinlerden konuları günlük yaşamla ilişkilendirmek, konuları pekiştirmek, öğrenci katılımını artırmak, konulara örnekler vermek, konunun daha iyi anlaşılmasını sağlamak, diğer derslerle ilişkilendirme yapmak, Atatürkçülük konularını işlemek, davranışlara işlevsellik kazandırmak, farklı disiplinlerden yararlanmak ve vatandaşlık konularını işlemek için yararlanmaktadır. Buna göre Sosyal Bilgiler dersinde ara disiplinlerden yararlanmanın konuları günlük yaşamla ilişkilendirmede önemli olduğunu düşünen öğretmenlerden biri bu görüşünü “Konuları sosyal hayatla bağdaştırıyoruz. Örneğin 'Vatandaşlık ve İnsan Hakları' konusu kapsamında sınıf içinde drama, video izleme, resim vb. çalışmalar yapıyoruz (Ö67). ” biçiminde açıklamıştır. Bu konuya ilişkin olarak bir diğer öğretmen ise görüşünü “...kazanımlarına yönelik çalışmalar 
Anadolu Journal of Educational Sciences International, July 2016, 6(2)

yaptım. Böylece ögrenciler konu ile günlük hayatı daha iyi ilişkilendirdiler. Yukarıdaki örnekteki gibi ara disiplinlerden konuların kavranmasında ve günlük hayatla ilişkilendirilmesinde faydalanıyoruz (Ö51).” biçiminde ifade etmiştir. Ara disiplinlerden yararlanmada konuların günlük yaşamla ilişkisini vurgulayan öğretmenler aynı zamanda derste kullanılan yöntem ve tekniklere de değinerek konuların daha iyi öğrenilmesini belirtmişlerdir. Sosyal Bilgiler dersinde ara disiplinlerden yararlanmanın öğrenci katılımını artırdığını düşünen öğretmenlerden biri bu görüşünü "Sosyal Bilgiler dersi hayatın içinden günlük yaşamımızla ilişkili olduğu için ögrencilerle sohbet havasında, tartışmalar eşliğinde, yapılan gözlemlerin, izlenimlerin aktarılmasıyla daha çok işlenmektedir. Kılavuz kitap ve program eşliğinde kazanımlara dikkat ederek ve ögrenci süreç içine çekilerek dersimizi işliyoruz. Ara disiplinler de buna olanak tanıyor $\ddot{O}(58)$." biçiminde açıklamıştır. Öğretmenin bu görüşünü Sosyal Bilgiler dersinin yapısıyla desteklediği görülmüștür. Ara disiplinlerden yararlanılan durumları sınıf öğretmenlerinden biri "Sınıf içinde, dramadan yararlanıyoruz, cd ve görsellerden yararlanıyoruz, araştırma çalışmalarını sınıfta paylaşıyoruz, düğer derslerle ilişkilendiriyoruz, Atatürkçülük konularına değiniyoruz (Ö65).” biçiminde açıklayarak farklı disiplinlere, araçgereçlere, diğer derslere ve Atatürkçülüğe değindiği görülmüştür. Görüşlerini “Öğrenilen konuların davranışlar haline getirilmesini sağlar... Davranışlara işlevsellik kazandırarak kalıcılık sağlar (Ö66).” biçiminde açıklayan bir diğer sınıf öğretmeninin ise ara disiplinlerin davranışlara olumlu yansıyacağına vurgu yaparak ara disiplinlerin yararlanıldığı durumları açıklamıştır. Sınıf öğretmenlerinin bu görüşlerinden yola çıkarak onların ara disiplinlerden yararlanılan durumlara ilişkin görüşlerini aynı zamanda ara disiplinlerin sağladığı olumlu özellikleri de ele alarak açıkladıkları söylenebilir. Sınıf öğretmenlerine göre Sosyal Bilgiler dersinde ara disiplinlerden yararlanmaya ilişkin yaşadıkları sorunlar Şekil 3’te gösterilmiştir. 


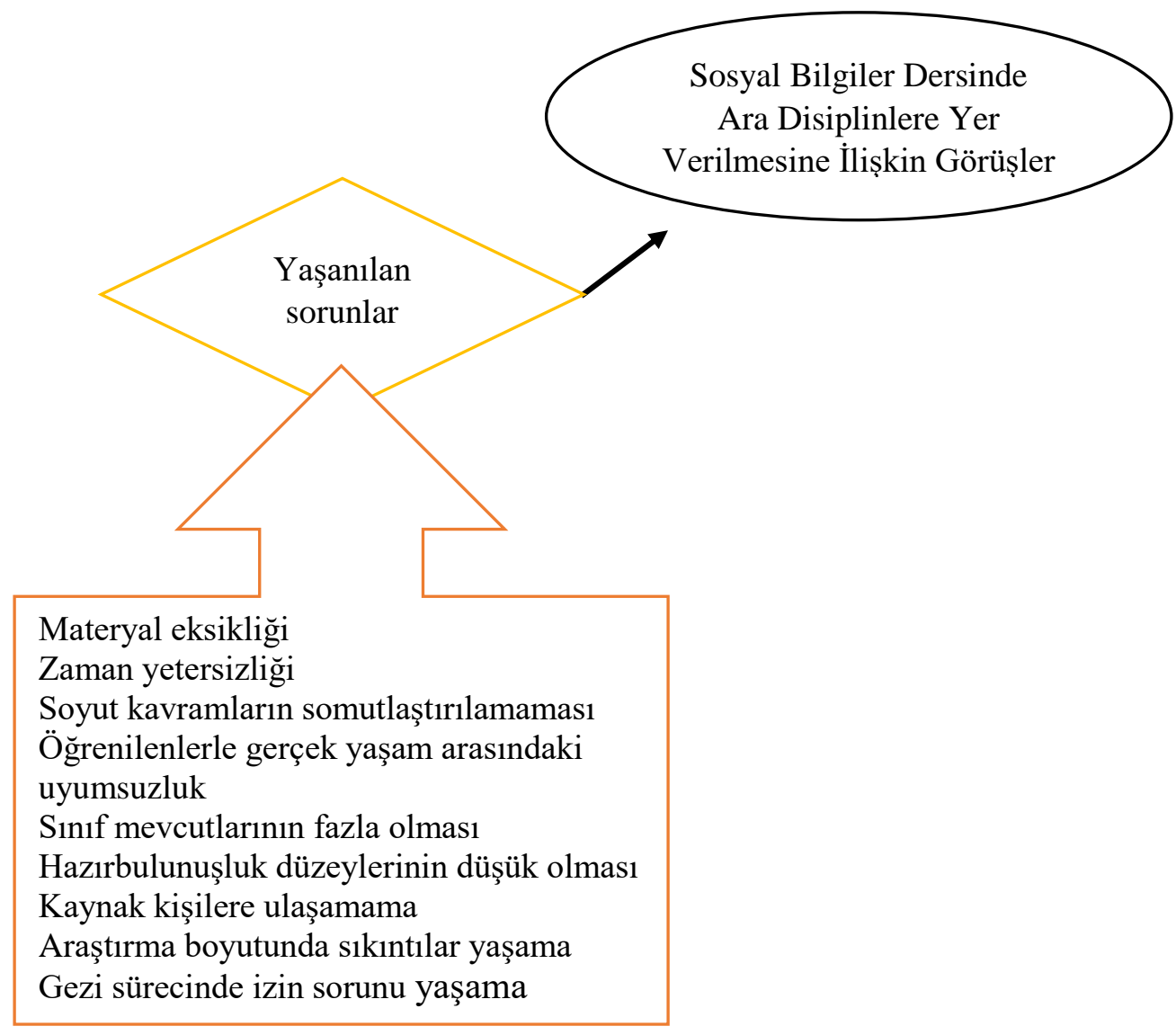

Şekil 3. Sosyal Bilgiler dersinde ara disiplinlerden yararlanmada yaşanılan sorunlar

Şekilde görüldüğü gibi, sınıf öğretmenleri Sosyal Bilgilerde ara disiplinlerden yararlanmada karşılaştıkları sorunları materyal eksikliği, zaman yetersizliği, soyut kavramların somutlaştırılmaması, öğrenilenlerle gerçek yaşam arasında bağ olmaması, sınıf mevcutlarının fazla olması, öğrencilerin hazırbulunuşluk düzeylerinin düşük olması, kaynak kişilere ulaşılamaması, araştırma yaparken sıkıntıların yaşanması ve gezi yapmak için izin sorunu yaşanması ile açıklamışlardır. Sosyal Bilgiler dersinde ara disiplinlerden yararlanmak için zaman yetersiz bulan sınıf öğretmenlerinden biri görüşünü “Tek sorun zamanın yetersiz kalması, belirli bir zamanda sıkıştırılmak zorunda kalıyor. (Ö58)” biçiminde açıklarken bir diğeri "Sosyal Bilgiler dersinde ara disiplinlere zaman ayırınca temel konulara yeterli zaman kalmıyor. Bunda tabi ki sınıfların kalabalık olması da ayrı bir etken. (Ö73).” biçiminde 
Anadolu Journal of Educational Sciences International, July 2016, 6(2)

açıklamıştır. Sınıf öğretmenleri konuları yetiştirme kaygısıyla ara disiplinlere zaman ayıramadıklarını vurgularken bunun nedenleri arasında sınıf mevcutlarını da göstermiştir. Görüşlerini "Sınıf içinde anlatılan doğru bilgilerle toplum içinde ve okul dışında yaşananlar arasındaki zıtlıklar ve örtüşmemeler boyutunda sıkıntı vardır (Ö61).” biçiminde açıklayan öğretmenlerden biri ise okul ile gerçek yaşam arasındaki bağlantıda sorunlar olduğunu ifade etmiştir. Sosyal Bilgilerde dersinde ara disiplinlerden yararlanmada kaynak kişilere ulaşmada sorun yaşadığını belirten öğretmenlerden biri bu görüşünü “Örneğin insanlarla yönetim konusunda vali, belediye başkanı gibi şehrin yönetici ve çevreyi güzelleştirme konusunda görüşmemiz gereken şahsiyetler var. Ancak onlarla bir görüşme ayarlamak mümkün olmuyor (Ö76). ” biçiminde açıklamıştır. Sınıf öğretmenlerin bir diğeri ise bu konudaki görüşünü “Bazı araç-gereçlere ulaşmak zor olabiliyor. Geziler için izin almak ve araç temin etmek sorun olabiliyor (Ö79).” biçiminde açıklayarak gerek materyal eksikliğine gerekse gezi-gözlem konusunda izin sürecine vurgu yapmıştır. Buna ilişkin olarak sınıf öğretmenlerinin ara disiplinlerden yararlanma konusunda araç-gereç boyutundan zamana, öğrenenlerin durumundan kaynak kişilere çok boyutlu sorunlar yaşadığı söylenebilir. Sınıf öğretmenlerinin Sosyal Bilgiler dersinde ara disiplinlerden yararlanılmasına ilişkin yaşadıkları sorunlara getirdikleri öneriler Şekil 4’te gösterilmiştir. 


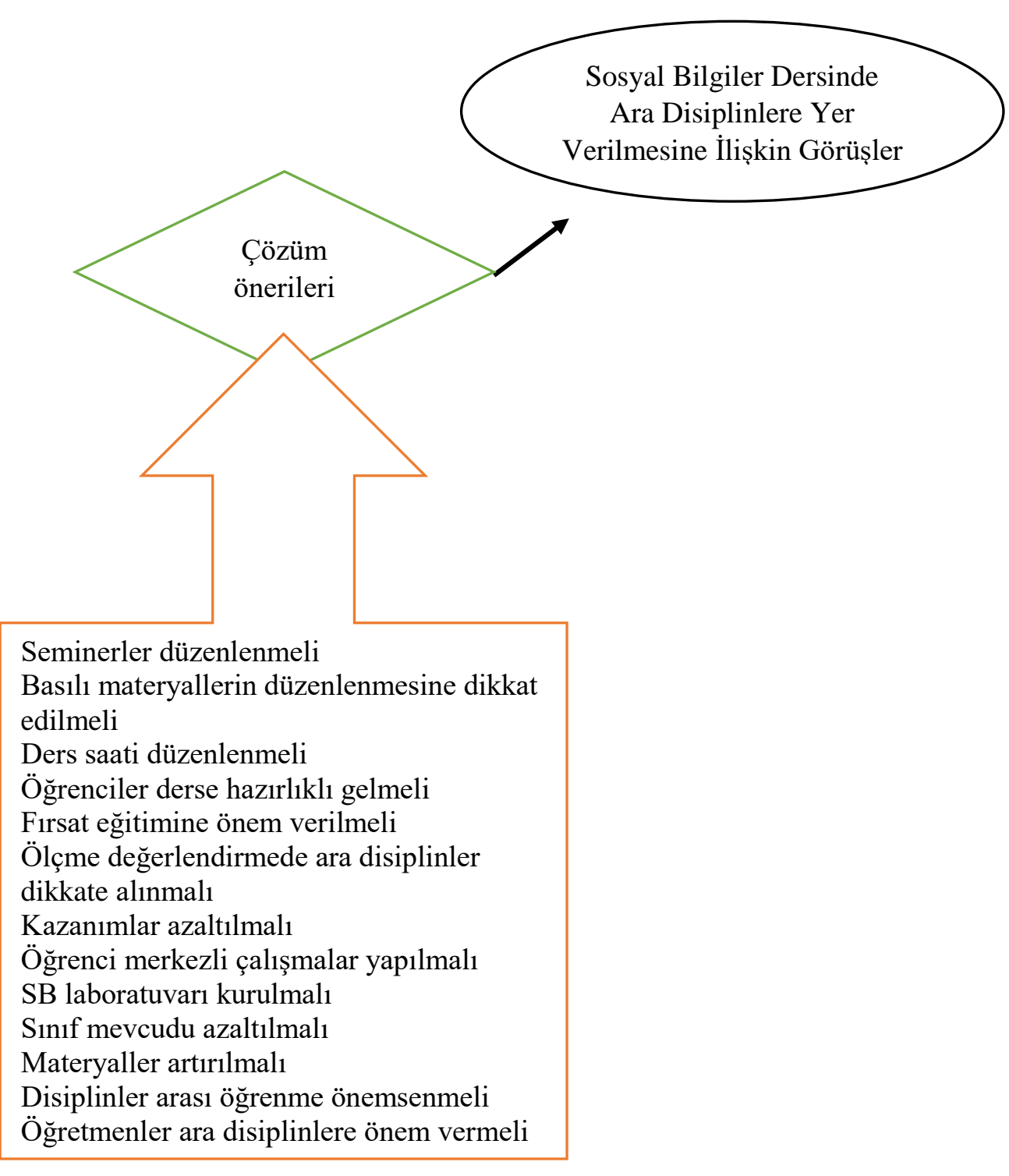

Şekil 4. Sosyal Bilgiler dersinde ara disiplinlerden yararlanmaya ilişkin çözüm önerileri

Şekilde görüldüğü gibi, sınıf öğretmenleri Sosyal Bilgiler dersinde ara disiplinlerden yararlanmaya ilişkin çözüm olarak seminerler düzenleme, basılı materyallerin düzenlenmesine dikkat etme ders saatini düzenleme, öğrencilerin derse hazırlıklı gelmesini sağlama, fırsat eğitimine önem verme, ölçme-değerlendirmede ara disiplinleri dikkate alma, kazanımları azaltma, öğrenci merkezli çalışmalar yapma, Sosyal Bilgiler laboratuvarları kurma, sınıf mevcutlarını azaltma, materyalleri artırma, disiplinler arası öğrenmeyi önemseme ve ara 
Anadolu Journal of Educational Sciences International, July 2016, 6(2)

disiplinlere önem verme önerilerini getirmişlerdir. Sınıf öğretmenlerinden biri Sosyal Bilgiler dersinde ara disiplinlerden daha etkili yararlanılmasına ilişkin olarak görüşünü "Sosyal bilgiler ders saatlerinin çoğaltılması ya da kazanımların azaltılması yoluna gidilebilir. Böylece ara disiplinlerle ilişkilendirme için daha fazla zaman kalabilir (Ö63).” biçiminde belirterek ders saati ve kazanım sayısına dikkat çekmiştir. Sosyal Bilgiler ders saatine ilişkin olarak başka bir sınıf ögretmeni ise "Ara disiplinlere zaman ayrllması ders saatlerine düzenleme getirilebilir (Ö58).” ifadelerini kullanmıştır. Sınıf öğretmenlerinden bir diğeri firsat eğitiminin önemini ve disiplinler arası öğrenmeyi ifade ederek görüşünü “Yer ve zamanlama yani firsat eğitimi ön planda tutulmalıdır. Yaparak yaşayarak ögrenmeye dayandırllmalıdır. Öğrencinin disiplinler arası bağlantı kurmasına yönelik rehberlik çalışmaları yapılmalıdır (Ö61).” biçiminde açıklamıştır. Görüşlerini öğrencilerin etkin katılımlarını ön plana alarak açıklayan sınıf öğretmenlerden biri bunu “Azda olsa zaman ayırmall. Öğrencilerin dikkatini çekecek çalışmalar yapmalı. Öğrencilerde merak uyandırmalı, araştırmaya yöneltmeli ve sınıfta paylaşmalarına firsat vermeli (Ö65).” biçiminde belirtmiş ve öğrenci merkezli eğitimin yapılmasına gerektiğini ifade etmiştir. Öğrenci merkezli çalışmalar yapılması gerektiğini bir başka öğretmen ise "Bu konularda öğrenci merkezli çalışmalar yapılmalı ve ilişkili kurumlara geziler düzenlenmesi çok yararlı olacaktır (Ö67)" biçiminde açıklayarak öğretim yöntem ve tekniklerinden gezi gözlemi ön plana çıkarmıştır. Buna göre öğretmenlerin önerilerini öğretim program, okul idaresi, öğretmen, Milli Eğitim Bakanlığı gibi boyutlarda ele aldıkları söylenebilir.

\section{Sonuç, Tartışma ve Öneriler}

Araştırma sonucunda 4. sınıfları okutan sınıf öğretmenlerinin Sosyal Bilgiler dersinde ara disiplinlerden yararlanılmasına ilişkin olarak öğrenci boyutunda çoğunlukla ara disiplinlerin afetten korunma ve güvenli yaşam konusunda temel bilgi ve becerileri kazandırdığını 
düşündükleri görülmüştür. Ayrıca öğretmenlerin Sosyal Bilgiler dersinde ara disiplinlerden yararlanmanın öğrencilerin haklarını nasıl koruyabileceği konusunda bilgi edinmesini ve farklılıklara karşı anlayış ve saygı göstermesini sağladığını belirttikleri sonucuna ulaşılmıştır. Yine öğretmenlerin Sosyal Bilgiler dersinde ara disiplinler sayesinde öğrencilerin sosyal problemlere karşı duyarlılık geliştirdiğini, vatandaşlıkla ilgili bilgi, beceri ve değerler kazandığını, araştırma, düşünme ve problem çözme becerilerinin geliştiğini düşündükleri görülmüştür. Sınıf öğretmenlerinin Sosyal bilgiler dersinde ara disiplinlerden yararlanmanın dikkat dağınıklığına neden olmadığını belirttikleri ortaya çıkmıştır. Bağlı (2013) tarafından yapılan araştırmada da öğrencilerin vatandaşlık ve insan hakları ara disiplini aracılığıyla vatandaşlık kazanımlarına ulaştığı sonucuna ulaşılmıştır. Dolayısıyla bu araştırmaların sonuçlarının vatandaşlık kazanımlarını gerçekleştirme anlamında örtüştüğü söylenebilir. Ancak Elkatmış (2012) yaptığı araştırmada insan hakları ve vatandaşlık ara disiplinin kazanımlarının yeterince gerçekleşmediğini ve uygulama boyutunda eksiklikler yaşandığını ortaya koymuştur. Bu bağlamda, Elkatmış'ın (2012) yaptığı araştırma sonucu ile bu araştırmanın öğrencilerin vatandaşlık konusunda bilgi, beceri ve değerler kazandığı sonucu ile benzerlik göstermediği söylenebilir.

Araştırmada sınıf öğretmenlerinin Sosyal Bilgiler dersinde ara disiplinlerle ilişkilendirmenin problemlere yol açmadığını, zaman kaybına neden olmadığını ve ek planlama gerektirmediğini düşündükleri sonucuna ulaşılmıştır. Barnes (2015) yaşama ilişkin tüm deneyimlerin birden fazla disiplini içerdiğini belirtmekte, dünyaya ilişkin her şeyin çoklu bakış açısıyla anlaşılabileceğini savunmaktadır. $\mathrm{Bu}$ nedenle Sosyal Bilgiler dersinde ara disiplin ilişkilendirmesinin önemli olduğu söylenebilir. Araştırmada ayrıca sınıf öğretmenleri Sosyal Bilgiler dersinde ara disiplinlerden yararlanma konusunda okulda işbirliği yapılması gerektiğini belirttikleri görülmüştür. Sınıf öğretmenlerinin ara disiplinler konusunda bilgilendirmelere gereksinim duyduklarını ifade ettikleri ortaya çıkmıştır. Ancak Gözütok ve Alkın (2008), 
Seçkin ve Gözütok (2010), Gültekin, Gürdoğan Bayır ve Göz (2013) ve Seçkin (2010) tarafından yapılan araştırmalarda öğretmenlerin ara disiplinlerin ek planlama gerektirdiğini, ön hazırlığa gereksinim duydukları ve derse ayrılan süreyi artırdığını düşünmesi bu araştırmada öğretmenlerin ek planlama gerektirmemesi ve zaman kaybına neden olmaması düşünceleri ile çelişmektedir.

Araştırmada sınıf öğretmenlerinin Sosyal Bilgiler dersinde ara disiplinlerden yararlanmanın güncel olaylarla bağlantı kurmayı sağladığını, ara disiplinlerin Sosyal Bilgiler dersinin yapısına uygun olduğunu, konuların pekişmesini sağladığını, kazanımların davranış haline dönüşmesini sağladığını ve günlük yaşamla ilişkilendirmeyi kolaylaştırdığını düşündükleri sonucuna ulaşılmıştır. Ayrıca sınıf öğretmenlerinin Sosyal Bilgiler dersinde ara disiplinlerden yararlanmanın programa zenginlik kattığını, programın eksik yönlerini tamamladığını ve ara disiplinlerin farklı disiplinlerden oluştuğunu düşündükleri görülmüştür. Sınıf öğretmenlerinin Sosyal Bilgiler Öğretim Programında ara disiplinlere ilişkin yapılan açıklamaları kısmen yetersiz buldukları ortaya çıkmıştır. Ermiş (2008) yaptığı araştırmada öğretmenlerin Sosyal Bilgiler Öğretim Programında ara disiplinlere ilişkin açıklamaları yetersiz bulduğu sonucuna ulaştığı için bu araştırmanın sonucu ile örtüşmektedir. Ayrıca Gözütok ve Alkın (2008) da yaptıkları araştırmada ara disiplinlere ilişkin yeterli açıklamanın yapılmadığını ortaya koyması nedeniyle bu araştırmanın açıklamaları yetersiz bulma sonucuyla örtüştüğü söylenebilir. Seikkula-Leino (2011), Finlandiya'da reform sırasında meslek liselerinin programlarına eklenen girişimcilik konusunun öğretimiyle ilgili öğretmenlerle gerçekleştirdiği çalışmasında öğretmenlerin girişimcilik eğitimini verme konusunda bilgi sahibi olmadıkları ve bu konuda eğitim desteğine ihtiyaç duydukları sonucuna ulaşmıştır. Programlarda ara disiplinlerle ilgili uygulamalarda öğretmenlere gerekli eğitim desteğinin verilmesinin öğretim çalışmalarının başarıya ulaşmasında çok önemli bir rol oynadığı söylenebilir. 
Araştırmada kullanılan ankette yer alan maddeler ile cinsiyet ve mezun olunan okul arasında anlamlı bir ilişki bulunmamıştır. Yalnızca ankette yer alan "ara disiplinlerle ilişkilendirme zaman kaybına neden olur." maddesi ile mesleki deneyim arasında anlamlı bir ilişki bulunmuştur.

Araştırma sınıf öğretmenlerinin Sosyal Bilgiler dersinde ara disiplinlerden konuları günlük yaşamla ilişkilendirmek, konuları pekiştirmek, öğrenci katılımını artırmak, konulara örnekler vermek, konunun daha iyi anlaşılmasını sağlamak, diğer derslerle ilişkilendirme yapmak, Atatürkçülük konularını işlemek, davranışlara işlevsellik kazandırmak, farklı disiplinlerden yararlanmak ve vatandaşlık konularını işlemek için yararlandıkları sonucuna ulaşılmıştır. Akyol (2015) de yaptığı araştırmada matematik öğretmenlerinin ara disiplinleri günlük yaşamla ilişkilendirme, öğrencileri güdüleme ve bilgilerin kalıcılığını sağlama amaçları ile kullandıklarını ortaya koyduğu için bu çalışmanın sonuçlarıyla benzerlik gösterdiği söylenebilir. Ayrıca Gözütok ve Alkın (2008) tarafından da yapılan araştırmada da benzer biçimde öğretmenlerin ara disiplinleri güncel olaylar ilişkilendirme, güdülenmeyi artırma ve günlük yaşamla ilişki kurma işlevlerinin olduğunu belirlenmiştir.

Araştırmada sınıf öğretmenlerinin Sosyal Bilgiler dersinde ara disiplinlerden yararlanma konusunda materyal eksikliği, zaman yetersizliği, soyut kavramların somutlaştırılmaması, öğrenilenlerle gerçek yaşam arasında bağ olmaması, sınıf mevcutlarının fazla olması, öğrencilerin hazırbulunuşluk düzeylerinin düşük olması, kaynak kişilere ulaşılamaması, araştırma yaparken sıkıntıların yaşanması ve gezi yapmak için izin alma zorluklarının olması sorunlarını yaşadıkları görülmüştür. Benzer biçimde Akyol'un (2015) matematik öğretmenleri ile ara disiplinlere ilişkin yaptığı araştırmada da öğretmenlerin zaman sıkıntısı yaşadıklarını görülmüştür. Yine Seçkin (2010) tarafından yapılan araştırmada da öğretmenlerin ara disiplinler için ek süreye gereksinim duyduklarını belirtmeleri ile bu araştırmada ortaya çıkan zaman sıkıntısı benzerlik göstermektedir. Gözütok ve Alkın (2008) ara disiplinlerin amaçlarına 
Anadolu Journal of Educational Sciences International, July 2016, 6(2)

ulaşmada sınıf mevcutlarının az olması gerektiği sonucu ortaya koyması bakımından bu araştırma ile paralellik gösterdiği söylenebilir. Yine Gözütok ve Alkın (2014) tarafından yapılan çalışmada ara disiplinlerden yararlanmada kaynak kişilere ulaşma ve geziler düzenleme önemli olduğu belirtilmiştir. Bu bağlamda, bu araştırmada sınıf öğretmenleri tarafından Sosyal Bilgiler dersinde ara disiplinlerden yararlanmada sorun olarak belirtilen kaynak kişilere ulaşılmama ve gezi yapmak için izin sorunun aşılması sorunlarına çözümler üretilebilir.

Araştırmada sınıf öğretmenlerinin Sosyal bilgiler dersinde ara disiplinlerden yararlanmada yaşadıkları sorunların giderilmesine ilişkin seminerler düzenleme, basılı materyallerin düzenlenmesine dikkat etme, ders saatini düzenleme, öğrencilerin derse hazırlıklı gelmesini sağlama, firsat eğitimine önem verme, ölçme-değerlendirmede ara disiplinleri dikkate alma, kazanımları azaltma, öğrenci merkezli çalışmalar yapma, Sosyal Bilgiler laboratuvarları kurma, sınıf mevcutlarını azaltma, materyalleri artırma, disiplinler arası öğrenmeyi önemseme ve ara disiplinlere önem verme önerilerini getirdikleri görülmüştür. Ara disiplinlere ilişkin yapılan diğer araştırmalarda da öğretmenlerin programın hafifletilmesi (Akyol, 2015; Ermiş, 2008), Sosyal Bilgiler ders saatinin artırılması (Ermiş, 2008) ve ara disiplinler konusunda gerekli bilgilendirmelerin yapılması (Akyol, 2015; Gözütok ve Alkın, 2008; Kansızoğlu, 2014; Seçkin, 2010; Taş, 2010) konusunda önerilerde bulunması bu araştırmanın seminerler düzenleme ve kazanımları azaltma sonuçları ile paralellik göstermektedir. ERG (2005) tarafından programlara ilişkin oluşturulan raporda ifade edilen ara disiplinlerle ilişkilendirmenin nasıl yapılacağının açık olmaması durumu öğretmenlerin bu konudaki seminer gereksinimine neden olabilir.

Araştırma sonucunda sınıf öğretmenlerinin Sosyal Bilgiler dersinde ara disiplinlerden yararlanmayı önemli gördükleri söylenebilir. Öğretmenlerin ara disiplinlerden yararlanmanın öğrencilere bilgi, beceri ve değerler kazandıracağını düşündükleri belirtilebilir. Ancak öğretmenlerin bu süreçte zaman konusunda sıkıntı yaşadıkları ortaya konulabilir. Ayrıca 
Anadolu Journal of Educational Sciences International, July 2016, 6(2)

öğretmenlerin Sosyal Bilgiler dersinde ara disiplinlerden yararlanma konusunda seminerlere gereksinim duydukları ve programa ilişkin ek bilgilendirmeler yapılması gerektiğini düşündükleri ifade edilebilir. Bu kapsamda araştırma sonuçlarına göre şu öneriler getirilebilir:

- Ara disiplinlerden yararlanılmasına ilişkin olarak paydaşlara eğitimler verilebilir.

- Öğretim programlarında ara disiplinlerle ilişkilendirmeye ilişkin açıklamalar yap1labilir.

- Ara disiplinlerle ilgili farklı veri toplama yöntemleri işe koşularak farklı araştırmalar yapılabilir.

- Bu araştırma farklı dersler için de tekrarlanabilir.

\section{Teșekkür}

Bu makalede katkıları geçen ancak bu süreçte aramızdan ayrılan Prof. Dr. Şefik YAŞAR'a teşekkürleri bir borç biliriz.

\section{Kaynakça}

Akyol, Ş. (2015). Matematik öğretmenlerinin ara disiplinlere ilişkin görüşleri. Mediterranean of Humanities (1), 61-75.

Bağlı, M. T. (2013). Ara-disiplin olarak vatandaşlık ve insan hakları eğitimi: ilköğretim öğrencilerinin insan haklarına ilişkin görüşleri. Eğitim ve Bilim, 38(169), 298-310.

Barnes, J. (2015). Cross-curricular learning 3-14. London: Sage Publications.

British Columbia Ministry of Education. (2013). Defining cross-curricular competencies. (Draft). https://www.bced.gov.bc.ca/irp/docs/def_xcurr_comps.pdf adresinden 05.01.2016 tarihinde edinilmiştir. 
Anadolu Journal of Educational Sciences International, July 2016, 6(2)

CCPE. (2008). Content of The Program of Programs, Cross-Curricular Competencies. http://www.ccpe.gouv.qc.ca/orienta/anglais/Append3.htm adresinden $\quad 01.02 .2016$ tarihinde edinilmiştir.

Çınkır, Ş. ve Demirkasımoğlu, N. (2015). Bilimsel araştırma yöntemleri gerçek dünya araştırması. Ş. Çınkır ve N. Demirkasımoğlu (Çev. Ed.) Ankara: Anı Yayıncılık.

Ekiz, D. (2013). Bilimsel araştırma yöntemleri. (Genişletilmiş 3. Baskı). Ankara: Anı Yayınc1lık.

Elkatmış, M. (2012). İnsan hakları ve vatandaşlık ara disiplini kazanımlarının gerçekleşme düzeyi. Akademik Bakış Dergisi, 29.

Eraslan, L. (2011). İlköğretim programlarında girişimcilik öğretimi (hayat bilgisi dersi örneği). Gazi Üniversitesi Endüstriyel Sanatlar Eğitim Fakültesi Dergisi, 27, 82- 94.

ERES. (2010). Development and evaluation of cross-curricular competencies: Where do we stand?

http://www.eres.fse.ulaval.ca/fichiers/site_eres/documents/Bulletins_de_transfert/BLTLSL-ANG-v2-220610.pdf adresinden 15.01.2016 tarihinde edinilmiştir.

ERG. (2005). Yeni programları inceleme ve değerlendirme raporu. İlköğretim Online, 5(1).

Erkuş, A. (2005). Bilimsel araştırma sarmalı. Ankara: Seçkin Yayıncılık.

Ermiş, S. (2008). Sosyal bilgiler dersinde ara disiplinlerin sınıf içi uygulamalarına ilişkin ögrretmen görüşleri. (Yayımlanmamış yüksek lisans tezi). Abant İzzet Baysal Üniversitesi, Bolu.

Finnish National Board of Education (2003). National core curriculum for upper secondary schools.

http://www.oph.fi/download/47678_core_curricula_upper_secondary_education.pdf adresinden 10.01.2016 tarihinde edinilmiştir. 
Anadolu Journal of Educational Sciences International, July 2016, 6(2)

Gözütok, D. ve Alkın-Şahin, S. (2014). Öğretim programlarında ara disiplin yaklaşımı. Ankara Üniversitesi Eğitim Bilimleri Fakültesi Dergisi, 47(2), 287-306.

Gözütok, F. D. ve Alkın, S. (2008). İlköğretim öğretmenlerinin programdaki ara disiplin yaklaşımına ilişkin görüşleri. International Conference on Educational Sciences ICES08. Kıbrıs: Doğu Akdeniz Üniversitesi, (23-25 Haziran) 839-853.

Gültekin, M., Gürdoğan Bayır, Ö. ve Göz, N. L. (2013). 2004 sosyal bilgiler öğretim programında yeni anlayışlar: 1998 öğretim programından farklılıkları açısından bir inceleme. Elektronik Sosyal Bilimler Dergisi, 46(46).

Kansızoğlu, H. B. (2014). Türkçe dersi öğretim programındaki ara disiplin alan kazanımlarına ilişkin bir araştırma. Dil ve Edebiyat Dergisi, 9. 75-95.

Karasar, N. (2007). Bilimsel araştırma yöntemi. Ankara: Nobel Yayıncılık.

Kaymakçı, S. (2012). Sosyal bilgiler öğretim programında ilişkilendirmeler. Abant İzzet Baysal Üniversitesi Eğitim Fakültesi Dergisi, 273-304.

MEB. (2004). Sosyal bilgiler 4.-5. sınıf programı. Talim ve Terbiye Kurulu Başkanlığı. http://ttkb.meb.gov.tr/ogretmen/modules.php?name=Downloads\&d_op=viewdownload $\&$ cid=74\&min=20\&orderby=titleA\&show=10 adresinden $\quad 25.12 .2008 \quad$ tarihinde edinilmiştir.

MELS (Ministère de l'Éducation, du Loisir et du Sport). (2008a). Cross-Curricular Competencies.

http://www1.mels.gouv.qc.ca/sections/programmeFormation/secondaire1/pdf/chapter3. pdf adresinden 05.02.2016 tarihinde edinilmiştir.

Naval, C., Print, M. ve Iriarte, C. (2003). Civic education in spain: a critical review of policy. Journal of Social Science Education, 2, 1-11.

Özdamar, K. (1999). Paket programlar ile istatistiksel veri analizi. Eskisehir: Kaan Kitabevi (2.Bask1). 
Anadolu Journal of Educational Sciences International, July 2016, 6(2)

Öztürk, Ş. (2008). Sosyal bilimler için veri analizi el kitabı. Ankara: Pegem Akademi Yayınları.

Seçkin, M. (2010). Fen ve teknoloji öğretim programı ara disiplin kazanımlarına ulaşılma düzeyi ve uygulamada yaşanan sorunlar. (Yayımlanmamış yüksek lisans tezi). Ankara Üniversitesi, Ankara.

Seçkin, M. ve Gözütok, F. D. (2010). Problems encountered in teaching cross curriculum skills of the science program. Procedia-Social and Behavioral Sciences, 9, 1319-1324.

Seikkula-Leino, J. (2011). The implementation of entrepreneurship education through curriculum reform in Finnish comprehensive schools. Journal of Curriculum Studies, 43(1), 69-85.

Taş, İ. D. (2010). 2005 ilkögretim programlarının hazırlanmasında görev alan ara disiplinler komisyonu üyelerinin ve sınıf öğretmenlerinin ara disiplin yaklaşımı konusundaki bilgi durumunun ve görüşlerinin belirlenmesi. (Yayımlanmamış yüksek lisans tezi). Ankara Üniversitesi, Ankara.

Ural, A. ve Kılıç, İ. (2005). Bilimsel araştırma süreci ve spss ile veri analizi. Ankara: Detay Yayınc1lık.

Vogt, M. (1997). Cross-curricular thematic instruction. https://www.eduplace.com/rdg/res/vogt.html adresinden 23.02.2016 tarihinde edinilmiştir.

Yıldırım, A. ve Şimşek H. (2006). Sosyal bilimlerde nitel araştırma yöntemleri. (Beşinci Baskı) Ankara: Seçkin Yayınevi. 


\section{Extended Abstract}

Cross-curricular themes took place in 2005 Social Studies Education Program as a new understanding. Cross-curricular themes are listed as disaster prevention and safe living, developing career awareness, entrepreneurship, sport culture and Olympic education, human rights and citizenship, special education, psychological guidance and counselling, and health culture in the Social Studies Education Program. Cross-curricular themes are the approaches which include curricular themes and extracurricular issues beside main courses. Moreover, cross-curricular themes play important role in multi-dimensional development of students. Cross-curricular themes can be practiced effectively if only teachers emphasize cross-curricular themes in the teaching-learning process. Therefore, teachers need to know how to integrate cross-curricular themes to the classroom activities. It can be said that in the literature, there are not adequate study about effect of cross-curricular themes on multi-dimensional development of students. In this context, purpose of this study to determine primary school teachers' views regarding using cross-curricular themes in the 4th grade Social Studies course. In the scope of main purpose these questions were addressed in the study:

- What is the frequency of 4th grade teachers' views about using cross-curricular themes in the social studies course?

- Are the views of the 4th grade teachers' about using cross-curricular themes in the social studies course differ in relation to their personal characteristics (gender, professional seniority, graduation program)?

- What are the 4th grade teachers' recommendations about using cross-curricular themes in the social studies course effectively?

Data of the study were collected through questionnaire consisted of open ended and close-ended questions. The universe of the study was the teachers from Tepebaş1, Eskişehir in 2013-2014 academic year. Simple random sampling was used in the study. 101 primary school teachers who were teaching at 4 th grade participated in the study. Percentage, frequency, and chi-square were used to analyze quantitative data while descriptive analysis was conducted to analyze qualitative data of the study. At the end of the study, it is seen that teachers pay attention to using cross-curricular themes in the Social Studies course. They think that cross-curricular themes help students gain various information, skills, and values. They need to cooperate with colleagues about cross-curricular themes. However, they have problems about timing, absence of materials, and resource people. They need seminars about this issue and they need extrainformation about cross-curricular themes in the education program. Also, a significant 
relationship was found between the item "cross-curricular themes integration causes about timing and professional experience. According to findings of the study the following suggestions can be put forth:

- seminars can be organized about using cross-curricular themes

- extra information can be added to the education program

- further researches can be designed through different data collection methods

- this research can be repeated for different courses. 